\title{
Neoliberalismo e Ciência Política: contribuições teóricas sobre a crise da democracia
}

\author{
Neoliberalism and Political Science: theoretical \\ contributions on the crisis of democracy
}

\section{Neoliberalismo y Ciencia Política: aportes teóricos sobre la crisis de la democracia}

\author{
iD (9) Juarez Rocha Guimarães \\ Universidade Federal de Minas Gerais, Belo Horizonte, Minas Gerais, Brasil \\ juarezrg15@gmail.com \\ iD Estevão Cruz \\ Universidade Federal de Minas Gerais, Belo Horizonte, Minas Gerais, Brasil \\ estevaocruz@gmail.com
}

\begin{abstract}
Resumo: Este artigo propõe uma reflexão, sistematização e orientação de uma ampla literatura internacional sobre o neoliberalismo, com o objetivo de trabalhar seu conceito político e tornar seu uso mais rigoroso, delimitado e regulado na Ciência Política. Com esse objetivo, o artigo inscreve o conceito na tradição histórica do liberalismo, por meio de um tratamento de filosofia política. Adota uma abordagem histórica e contextual para estruturar uma narrativa do processo de expansão política do neoliberalismo, identifica a ascensão do neoliberalismo como princípio de legitimação dos Estados e, por fim, aponta sinteticamente a relação entre o predomínio do neoliberalismo e as mudanças legais e constitucionais no Estado liberal. Como conclusão, são apresentadas algumas contribuições teóricas que esse conceito político de neoliberalismo pode oferecer para a reflexão contemporânea sobre os impasses da democracia.
\end{abstract}

Palavras-chave:Neoliberalismo. Liberalismo. Ciência Política. Democracia. Estado. 


\begin{abstract}
This article proposes a reflection, systematization, and orientation of a broad international literature on neoliberalism, aimed at working on its political concept and making its use more rigorous, delimited, and regulated in Political Science. With this objective in view, the article inscribes the concept in the historical tradition of liberalism, through an approach grounded in political philosophy. It follows a historical and contextual approach to structure a narrative of the political expansion process of neoliberalism, identifies the rise of neoliberalism as a legitimizing principle of the States and, finally, summarizes the relationship between the predominance of neoliberalism and the legal and constitutional changes in the liberal State. In conclusion, some theoretical contributions that this political concept of neoliberalism can offer for contemporary reflection on the deadlocks of democracy are introduced.
\end{abstract}

Keywords: Neoliberalism. Liberalism. Political Science. Democracy. State.

Resumen: Este artículo propone una reflexión, sistematización y orientación de una amplia literatura internacional acerca del neoliberalismo, con el objetivo de trabajar su concepto político y hacer más riguroso, delimitado y regulado su uso en la Ciencia Política. Con este objetivo en mente, el artículo inscribe el concepto en la tradición histórica del liberalismo, a través de un enfoque basado en la filosofía política. Sigue un enfoque histórico y contextual para estructurar una narrativa del proceso de expansión política del neoliberalismo, identifica el ascenso del neoliberalismo como principio legitimador de los Estados $y$, finalmente, resume la relación entre el predominio del neoliberalismo y los cambios legales y constitucionales en el Estado liberal. En conclusión, se introducen algunos aportes teóricos que este concepto político del neoliberalismo puede ofrecer para la reflexión contemporánea acerca de los impasses de la democracia.

Palabras clave: Neoliberalismo. Liberalismo. Ciencia Política. Democracia. Estado.

Data de recebimento: 25/10/2019

Data de aprovação: 15/06/2020 
Neoliberalismo e Ciência Política: contribuições teóricas sobre a crise da democracia Juarez Rocha Guimarães • Estevão Cruz

Este artigo se propõe a um trabalho de reflexão e sistematização do conceito político neoliberalismo como caminho necessário para incorporá-lo ao diálogo acadêmico que hoje se faz em torno dos impasses contemporâneos da democracia na área da Ciência Política?'.

A reflexão e a sistematização desse conceito político são necessárias por três razões. Em primeiro lugar, há uma nítida e crescente defasagem entre o acúmulo que se construiu na literatura acadêmica internacional na última década e o seu estágio muito inicial no Brasil. Um painel de estudos sobre o neoliberalismo em âmbito internacional pode ser encontrado em duas compilações mais recentes (CAHILL et al., 2018; SPRINGER et al., 2016). A própria relação entre neoliberalismo e democracia tem sido objeto de um conjunto de trabalhos (BIEBRICHER, 2019, 2015; DARDOT, LAVAL, 2016; BROWN, 2019, 2015; STREECK, 2013; CROUCH, 2011, 2001; COULDRY, 2010; HARVEY, 2008).

No Brasil, a circulação e, sobretudo, a produção de reflexões na área de Ciência Política sobre o conceito e o tema ainda são escassas. Uma pesquisa no portal de periódicos Scielo a partir do termo "neoliberalismo" retorna 104 artigos publicados entre os anos de 2011 e 2020, na área de Ciência Política e afins². Ainda assim, quase a totalidade desses artigos utiliza o termo com uma abordagem economicista para tratar temas diversos que vão da educação à sociologia das elites, da financeirização às teorias feministas, dos direitos humanos às políticas públicas de bem-estar social, entre outros. Excetuam-se poucos artigos dedicados a sistematizar a discussão sobre o conceito de neoliberalismo e/ou a evidenciar o seu significado propriamente político (ANDRADE, 2019a, 2019b; LAVAL, 2017; AVELINO, 2016).

Em segundo lugar, o neoliberalismo se encaixa certamente na condição de um conceito político historicamente contestado, carregado de criticidade, que pode ter o seu significado contin-

\footnotetext{
10 artigo desdobra-se da dissertação de mestrado “Neoliberalismo e destruição da democracia: uma abordagem marxista na Ciência Política", defendida pelo autor (CRUZ, 2019).

2 Consulta realizada em 31 de maio de 2020 com os seguintes parâmetros: 1) termo: neoliberalismo/todos os índices; 2) filtros: a. coleção Brasil; b. ano de publicação 2011 a 2020; c. áreas temáticas Ciências Políticas e Ciências Sociais Aplicadas; d. WoS áreas temáticas Sociologia, Ciência Política, Ciências Sociais/interdisciplinar, Humanidades/multidisciplinar, Estudos Culturais.
} 
Neoliberalismo e Ciência Política: contribuições teóricas sobre a crise da democracia Juarez Rocha Guimarães • Estevão Cruz

gencialmente disputado (SILVA, 2011; BALL, 2002). A expansão e o aprofundamento recentes das pesquisas, a partir de diferentes perspectivas epistemológicas, teóricas e metodológicas, tornaram ainda mais complexo o problema da definição conceitual e incontornável o debate sobre a utilidade do conceito.

Mesmo reconhecendo a contestabilidade de grande parte dos conceitos mobilizados nas Ciências Sociais, Bill Dunn (2016) polemiza o uso do termo neoliberalismo apontando que a sua atual difusão não decorreria de maior estabilização do conceito, mas, ao contrário, criaria importantes obstáculos para a precisão conceitual. Para este autor, a imprecisão do termo levaria a que "aceitemos que tudo e todo lugar é neoliberal" (ibidem, p. 4). Taylor C. Boas e Jordan Gans-Morse (2009, p. 139), a partir de uma extensa revisão bibliográfica em revistas de política comparada, desenvolvimento e estudos latino-americanos entre 1990 e 2004, afirmam não encontrar "um único artigo focado na definição e uso do neoliberalismo, nem estamos cientes de algum publicado em outro lugar". Esses autores esperam, entretanto, que um trabalho do conceito contribua para o mesmo "tipo de processo que transformou outros termos politicamente carregados como corporativismo ou totalitarismo em ferramentas analíticas úteis" (ibidem).

Diversos outros autores participam desse debate defendendo o uso do termo e propondo definições conceituais (MUDGE, 2016; PECK, BRENNER, THEODORE, 2018; CAHILL, KONIGS, 2017; BIEBRICHER, 2019). Damien Cahill e Martijn Konigs $(2017$, p. 6) defendem que "um termo como o neoliberalismo não é, por si só, capaz de captar as dinâmicas complexas e confusas e os detalhes variados das formações sociais", mas acrescentam que "a questão é, antes, se ele fornece um ponto de entrada útil, uma maneira de olhar para esses processos que podem ser posteriormente enriquecidos com detalhes empíricos" (ibidem). Em um sentido semelhante, Thomas Biebricher $(2019$, p. 6) entende que definir conceitualmente o neoliberalismo não implica dificuldades maiores do que as existentes para definir tradições políticas como o liberalismo, o conservadorismo ou o socialismo. 
Neoliberalismo e Ciência Política: contribuições teóricas sobre a crise da democracia Juarez Rocha Guimarães • Estevão Cruz

O conceito de neoliberalismo deve responder, portanto, a uma tripla camada de controvérsias. Aquela que consulta o dicionário controverso da Ciência Política, formada pelo encontro de muitas tradições e linguagens políticas, outra que diz respeito à contemporaneidade do fenômeno, à sua breve história e à sua variação contextual. E, por fim, aquela que percorre a própria literatura sobre o neoliberalismo, muito longe de estar unificada ou assentada em um paradigma conceitual claramente hegemônico. Daí a necessidade de sempre utilizar o conceito de neoliberalismo em um sentido crítico, aberto à polêmica e com um potencial de explicação controlado.

Em terceiro lugar, o uso mais generalizado do termo neoliberalismo nas últimas décadas foi claramente em um sentido economicista e macroestrutural, de superação de uma época dominada pelo keynesianismo e pelos Estados do Bem-Estar Social (CAHILL; KONIGS, 2017, p. 4). Só nos anos mais recentes o conceito de neoliberalismo ganhou enfoques mais politizados, abordando o sentido filosófico singular de sua teoria, suas relações com as teorias democráticas, suas implicações para a cultura e a sociabilidade democráticas e para os modos institucionais de regulação do Estado. O conceito de neoliberalismo deve ser compreendido, ainda, no espectro plural das linguagens liberais e em posição normativa adversária aos seus paradigmas e vocabulários dominantes.

A defasagem da Ciência Política brasileira na recepção da literatura sobre o neoliberalismo, as dificuldades e preocupações metodológicas em torno da sua precisão conceitual e o caráter polêmico e adversativo do seu significado justificam a necessidade de um trabalho de reflexão e sistematização do conceito. Este artigo argumenta, de forma ponderada, que este trabalho pode contribuir para a sua utilização pela Ciência Política.

O artigo será construído em quatro partes. A primeira abordará, de modo sintético, a singularidade do neoliberalismo, sua diferença com o liberalismo clássico e sua forte crítica ao chamado liberalismo social ou igualitário, bem como seu pluralismo e sua unidade. Na segunda parte, com um enfoque mais histórico e con- 
Neoliberalismo e Ciência Política: contribuições teóricas sobre a crise da democracia Juarez Rocha Guimarães • Estevão Cruz

textual, o neoliberalismo em seu processo de expansão política será interpretado como a crescente destruição do horizonte da época marshalliana, de construção e universalização dos direitos, no pós-Segunda Guerra. Também de modo sintético, a terceira parte abordará como o neoliberalismo imprime a corrosão dos valores da sociedade democrática, formando novos princípios hegemônicos de legitimação de Estados não democráticos. A quarta parte procurará tratar da ampla modificação neoliberal da institucionalidade do Estado democrático em todas as áreas das políticas públicas e do próprio processo de controle e renovação democrática dos governos. A conclusão buscará abordar o que se ganha com um conceito político de neoliberalismo assim construído para se entender os impasses atuais da democracia.

\section{Neoliberalismo: filosofia e teoria democrática}

Na aula ministrada em 14 de fevereiro de 1979, no curso sobre o "Nascimento da Biopolítica", Michel Foucault (2008, p. 182) fez referência a um documento que trazia o resumo dos debates do Colóquio Walter Lippmann - CWL (Paris, 1938). Esse documento permite resgatar o CWL como o primeiro momento de identificação da singularidade do neoliberalismo enquanto uma própria revisão, crítica e atualização do liberalismo no século XX³ .

No CWL reuniram-se 26 intelectuais ${ }^{4}$, a convite do filósofo francês Louis Rougier, para recepcionar o jornalista norte-americano Walter Lippmann e discutir o seu livro "The Good Society", traduzido em francês como "La Cité Libre" (REINHOUDT; AUDIER, 2018). Rougier, no convite enviado, afirma que o objetivo do CWL é "discutir as teses centrais desse trabalho, que dizem respeito ao declínio do liberalismo e das condições para o retorno de uma ordem liberal renovada, distinta do laissez-faire manchesteriano"

\footnotetext{
3 Uma apresentação contextualizada das intervenções pode ser encontrada em Jurgen Reinhoudt e Serge Audier (2018). 4 Em Reinhoudt e Audier (2018) encontra-se uma lista dos participantes e outros convidados ausentes, dentre os quais Friedrich Heyek, que seria um dos intelectuais mais identificados ao neoliberalismo, mas também Raymond Aron, que se aproximaria mais de um liberalismo social.
} 
Neoliberalismo e Ciência Política: contribuições teóricas sobre a crise da democracia Juarez Rocha Guimarães • Estevão Cruz

(ROUGIER, Louis apud REINHOUDT; AUDIER, 2018, p. 9). Na apresentação que faz das discussões do CWL, Rougier informa que elas "esboçaram os contornos de uma doutrina chamada por alguns de 'constructor liberalism', referida por outros como 'neo-capitalism', e para a qual o uso do nome 'neo-liberalism' parece prevalecer" (idem, p. 93).

Quais seriam esses contornos que singularizam esse neoliberalismo em face do liberalismo clássico ou do laissez-faire manchesteriano? As teses de Lippmann, conforme Rougier argumenta, "demonstraram que a economia de mercado não foi [...] um resultado espontâneo da ordem natural, mas o resultado de uma ordem legal na qual a intervenção estatal foi uma precondição" (idem, p. 7, grifo nosso). Essas teses encontravam eco nas reflexões dos próprios intelectuais participantes e formavam o ponto de convergência, em meio a várias divergências, do CWL (REINHOUDT; AUDIER, 2018). Reinhoudt e Audier (2018, p. 24) resumem que para a maioria dos participantes "o Estado teve que estabelecer pró-ativamente as instituições que produziriam e sustentariam o adequado funcionamento do mecanismo de preço de mercado".

Esteve também entre os objetivos do CWL a formação de um movimento intelectual e político que construísse um sistema teórico coerente e um programa de ação, que foi forçosamente interrompido pela eclosão da II Guerra Mundial. Em 1947, formou-se a Sociedade Mónt-Pèlerin - SMP, reunindo novamente alguns dos mesmos intelectuais e retomando temas discutidos no CWL, agora com muito mais identidade epistemológica, filosófica e programática (PLEWHE; MIROWSKI, 2009). A partir desse momento, esses intelectuais definiram mais claramente a tarefa de revisar teoricamente o liberalismo clássico combatendo, ao mesmo tempo, os chamados coletivismos, que iam do liberalismo keynesiano ao socialismo.

Para tanto, o trabalho que começou a se desenvolver na SMP concentrou-se no estabelecimento de compromissos epistêmicos, de valores e princípios compartilhados. Dieter Plewhe (2009, p. 22-4) traz algumas das posições comuns esboçadas pelos parti- 
Neoliberalismo e Ciência Política: contribuições teóricas sobre a crise da democracia Juarez Rocha Guimarães • Estevão Cruz

cipantes da primeira reunião, que permitem identificar a agenda intelectual dos neoliberais. Dentre elas, como sintetizado anteriormente (CRUZ, 2019): a defesa de que a liberdade individual só é possível em uma sociedade de mercado competitivo e sem planejamento central dos recursos; a noção de que essa ordem competitiva depende de um quadro jurídico e institucional adequado e continuamente adaptável; a limitação da atividade governamental pelo direito, fundamentado na propriedade privada e nos códigos morais.

Nota-se, então, que o neoliberalismo forma a sua identidade enquanto um liberalismo renovado a partir de outra ontologia do social, outra epistemologia e outra filosofia política. Isto é, se o fundamento do liberalismo de uma liberdade individual vinculada à sociedade mercantil competitiva é preservado, agora se entende que essa sociedade mercantil não é natural, mas precisa ser politicamente construída com base na propriedade privada e nos fundamentos morais costumeiros - e não na vontade democrática.

Identificando essa singularidade e já se debruçando sobre as formas práticas de implementação do neoliberalismo, Foucault (2008) avalia que há uma mudança do próprio sentido do poder político. Enquanto no liberalismo clássico o poder é exclusivamente repressivo e precisa ser constrangido para não ameaçar a ordem privada-mercantil, no neoliberalismo o poder é também produtivo, criador, e deve ser regulado para forjar a ordem de mercado. Segundo ele (idem, p. 181), diferentemente do "liberalismo do tipo Adam Smith, no liberalismo do século XVIII", o problema do neoliberalismo não era o de saber

como, no interior de uma sociedade política já dada, era possível recortar, arranjar um espaço livre que seria o do mercado. O problema do neoliberalismo é, ao contrário, saber como se pode regular o exercício global do poder político com base nos princípios de uma economia de mercado. 
Neoliberalismo e Ciência Política: contribuições teóricas sobre a crise da democracia Juarez Rocha Guimarães • Estevão Cruz

Isto é, mais do que proteger a liberdade do mercado diante da intervenção do Estado, a questão seria a de afirmar a liberdade como um valor inerente ou imanente à própria lógica do mercado e instituir um Estado baseado neste e promotor deste princípio. Essa concepção de liberdade radicalizaria a sua cisão ou sua oposição ao valor da igualdade, oposto, em tudo, ao chamado liberalismo social, igualitário ou keynesiano. Conforme essa filosofia política neoliberal, em um regime liberal, o Estado deve instituir política e juridicamente o princípio da concorrência mercantil como critério absoluto e meio eficaz no qual os indivíduos poderiam agir livremente para a consecução dos seus fins (CRUZ, 2019, p. 69). Como afirmam Pierre Dardot e Christian Laval (2016, p. 19, grifos dos autores), para os neoliberais não se trata de "governar contra a liberdade ou a despeito da liberdade, mas governar pela liberdade, isto é, agir ativamente no espaço de liberdade dado aos indivíduos para que estes venham a conformar-se por si mesmos a certas normas".

Com maior ou menor diálogo com Foucault, essa singularidade vem sendo destacada por diversos intérpretes contemporâneos que recuperam os debates políticos e filosóficos dos intelectuais neoliberais em seus contextos e seus desenvolvimentos históricos (BROWN, 2019; BIEBRICHER, 2019; REINHOUDT; AUDIER, 2018; DARDOT; LAVAL, 2016; PLEWHE; MIROWSKI, 2009; HARVEY, 2008; TURNER, 2007).

Se essa singularidade pode ser assim identificada, os desenvolvimentos históricos particulares do "neoliberalismo realmente existente" (PECK; BRENNER; THEODORE, 2018) marcam o pluralismo de suas principais correntes. Destaca-se uma vez mais o mérito de Foucault (2008) em apontar, ainda antes da virada neoliberal do início dos anos 1980, as características particulares do liberalismo alemão, ou ordoliberalismo, dos anos 1942-1962, e do neoliberalismo americano da Escola de Chicago. Para Foucault (2008, p. 438)

o ordoliberalismo, trabalhando sobre os temas fundamentais da tecnologia liberal de governo, procurou definir o que poderia ser uma economia de mercado, organizada (mas não planejada 
Neoliberalismo e Ciência Política: contribuições teóricas sobre a crise da democracia Juarez Rocha Guimarães • Estevão Cruz

nem dirigida) no interior de um quadro institucional e jurídico, que, de um lado, proporcionaria as garantias e limitações da lei e, de outro, garantiria que a liberdade dos processos econômicos não produzisse distorção social.

A Escola de Chicago, opondo-se à política econômica que atravessou o período entreguerras e dos governos democratas do pós-Segunda Guerra nos EUA, proporia um caminho alternativo ao do ordoliberalismo. Segundo Foucault (idem, p. 438-439),

enquanto este considera que a regulação dos preços pelo mercado [...] é, de per si, tão frágil que precisa ser sustentada, arranjada, "ordenada" por uma política interna e vigilante de intervenções sociais [...] esse neoliberalismo americano procura, em vez disso, ampliar a racionalidade do mercado [...] a campos não exclusivamente ou não primordialmente econômicos.

Vinculando, de modo mais largo e orgânico, essas reflexões às próprias dinâmicas do capitalismo financeiro contemporâneo, Wendy Brown (2019; 2015) quer demonstrar como este novo princípio neoliberal corrói as próprias bases da ordem liberal democrática. Apoiando-se, sobretudo, nas características da corrente norte-americana e suas tendências contemporâneas de universalização, Brown (2015, p. 44) argumenta que o neoliberalismo é "a racionalidade através da qual o capitalismo finalmente devora a humanidade". Para ela, nesse momento, é a expansão da racionalidade econômica do capitalismo financeiro que transforma tudo em vida econômica (BROWN, 2015, p. 35) e as subjetividades em capital humano cada vez mais financeirizado (idem, p. 44).

Em recente trabalho, Brown (2019) revisa e incorpora a essa tese o argumento de que não é apenas a racionalidade econômica, mas também uma moralidade conservadora, heteronormativa e branca, que, juntas, corroem as bases igualitárias da ordem liberal democrática. A autora recupera trechos da "Declaração de Objetivos" da SMP, nos quais se destacam tanto a questão econômica quanto moral, e os trabalhos de Hayek para quem, segundo 
Neoliberalismo e Ciência Política: contribuições teóricas sobre a crise da democracia Juarez Rocha Guimarães • Estevão Cruz

Brown (2019, p. 23), “o mercado e a moral, juntos, são o fundamento da liberdade, da ordem e do desenvolvimento da civilização".

Visitando criticamente o campo plural do pensamento político neoliberal, Thomas Biebricher (2019) documenta como esses novos fundamentos filosóficos estabelecem pontos de cisão e corrosão das teorias liberal-democráticas da Ciência Política. Para o autor (idem, p. 79), o problema das pré-condições políticas de funcionamento da ordem de mercado e da necessidade do Estado ocupa, de forma variada, o pensamento neoliberal e é a partir dele que os debates sobre a democracia são feitos. Biebricher (ibidem) identifica dois núcleos de controvérsias: um primeiro, crítico aos aspectos pluralistas da democracia representativa liberal; outro, crítico ao suposto excesso de poder popular nesses regimes.

Em trabalho anterior, esse autor havia mapeado dois principais campos de resposta a essas críticas, muitas vezes articulados pelos mesmos intelectuais (BIEBRICHER, 2015). Haveria um campo que defende a restrição da democracia representativa através de variadas formas de instituições não majoritárias, regras autovinculantes ou do domínio tecnocrático. Biebricher (2015) localiza aqui o ordoliberalismo alemão e autores como Walter Eucken, Alexander Rüstow e Wilhelm Röpke, que formularam soluções elitistas e autoritárias de transferir decisões governamentais e econômicas para uma tecnocracia imune à disputa democrática. Segundo Biebricher (idem), autores como Hayek, Milton Friedman e James Buchanan dedicaram argumentos da necessidade da imposição de normas compulsórias e constitucionais que limitem a arbitragem democrática sobre a economia mercantil, a política monetária e orçamentos públicos. Biebricher (2019; 2015) exemplifica como esses argumentos calçariam a legitimidade das estruturas decisórias do Banco Central Europeu, bem como o Eurozone Fiscal Pact.

Outro campo argumentativo propõe substituir a regulação por procedimentos democráticos pela coordenação direta das dinâmicas mercantis. Aqui, para Biebricher (idem), o argumento principal é o de Friedman quanto à substituição da soberania do cidadão pela soberania do consumidor. É desse autor a passagem expres- 
Neoliberalismo e Ciência Política: contribuições teóricas sobre a crise da democracia Juarez Rocha Guimarães • Estevão Cruz

siva que se transformou em lugar comum na cultura neoliberal contemporânea. Diz ele (FRIEDMAN, 1980, p. 66 apud BIEBRICHER, 2015, p. 260):

Quando você vota cotidianamente no supermercado, você recebe precisamente o que você elegeu, e assim é para todo mundo. A urna produz conformidade sem unanimidade; o mercado, unanimidade sem conformidade. Assim é porque só é desejável usar a urna de votos, tanto quanto possível, apenas para decisões para as quais a conformidade é essencial.

Uma análise das democracias contemporâneas registraria as evidências, por certo com as mediações de casos particulares, de como esse princípio de substituir mecanismos democráticos decisórios por sistemas alocativos de mercado tem se generalizado.

Há, decerto, relações genéticas e de afinidade entre a mudança de paradigma que o neoliberalismo veio conformando no interior da tradição liberal e as grandes transformações nas democracias ocidentais nas últimas décadas. Mas é necessário compreender a história e a organicidade dos caminhos do pensamento neoliberal nos centros de poder político e econômico do mundo.

\section{A corrosão do homo politicus marshallianus}

A ascensão neoliberal de um lugar marginal e, depois, minoritário no interior da tradição liberal, até se tornar hegemônica, não deve ser pensada como uma história auto-referida de ideais que deram certo. O desafio é bem mais complexo: trata-se de pensar historicamente como um corpo coletivo de ideias-força, disputando o lugar central no interior da tradição liberal com o chamado liberalismo keynesiano, tornou-se orgânico. Em outras palavras, trata-se de pensar como se tornou um programa político de atores estrategicamente situados nos países capitalistas centrais, fundindo grandes massas de poder político e econômico, estabelecendo 
Neoliberalismo e Ciência Política: contribuições teóricas sobre a crise da democracia Juarez Rocha Guimarães • Estevão Cruz

novas institucionalidades internacionais e nacionais, construindo, enfim, um novo senso comum e um novo horizonte político.

Para identificar essa grande e dramática mudança de época, Brown (2015, p. 35) aborda as consequências gigantescas da derrota do "anêmico homo politicus da democracia liberal" para as instituições, culturas e os imaginários da democracia. As consequências foram certamente gigantescas, mas não seria exato falar da derrota de um anêmico homo politicus da democracia liberal em geral.

A qualificação anêmica valeria apenas para liberalismos mais elitistas - o chamado "elitismo democrático" - e algumas vertentes mais institucionalistas do liberalismo. Por sua vez, a tradição do liberalismo social ou keynesiano, que foi dominante entre os anos 1945 até fins dos anos 1970, incentivou ou conviveu com um conjunto de experiências de ativismo partidário ou parlamentar, sindical ou corporativo, de participação social e de movimentos por direitos civis ou novos direitos, que, certamente, em graus variados, formou a base democrática dos Estados do Bem-Estar Social.

Para ser bem compreendida, portanto, a proporção gigantesca da mudança de época deveria dizer da derrota do homo politicus marshallianus e não de forma generalizada do homo politicus liberal. Esse homo politicus marshallianus, expressivo da cultura e da imaginação de T.H. Marshall (1967), em "Cidadania, Classe Social e Status", seria aquele que apostaria na possibilidade de, através da pressão eleitoral e da pressão cívica no contexto da democracia liberal, progressivamente ampliar e universalizar os direitos de cidadania, de tal maneira a relativizar e superar as desigualdades classistas do capitalismo. Entendido assim, além de abarcar as várias gerações de teorias e tradições do chamado liberalismo social ou igualitário - de Norberto Bobbio a John Rawls e Jurgen Habermas, passando pelas teorias do reconhecimento e deliberativas -, o homo politicus marshallianus designaria também as correntes do trabalhismo, da socialdemocracia e do próprio eu- 
Neoliberalismo e Ciência Política: contribuições teóricas sobre a crise da democracia Juarez Rocha Guimarães • Estevão Cruz

rocomunismo que apostaram historicamente no progressivismo ilimitado da democracia liberal.

A ascensão das correntes neoliberais ao centro dominante da tradição liberal, aos centros de poder e dinheiro do mundo, porém, renovou os obstáculos históricos e estruturais ao progressivismo da democracia liberal. Mais do que isso, têm imposto uma dinâmica regressiva dos direitos e uma forte desconstrução das dimensões democráticas da ordem liberal (DARDOT; LAVAL, 2016; STREECK, 2013; 2012; ABREU, 2008).

Uma narrativa unitária dessas grandes mudanças políticas históricas já foi razoavelmente construída na literatura internacional sobre o neoliberalismo (DARDOT; LAVAL, 2016; HARVEY, 2008). Deveríamos identificar cinco períodos nessa grande narrativa: a gênese, a ascensão, a formação da agenda, a construção hegemônica e o período da crise e agudização das dinâmicas antidemocráticas.

O período de gênese do neoliberalismo é identificado como o momento de formação de um movimento transnacional de pensamento coletivo. Como visto na seção anterior, o evento seminal teria sido o CWL (REINHOUDT, AUDIER, 2018; DARDOT; LAVAL, 2016). Além dos debates fundadores ali travados, foi criado o Centro de Estudos para a Renovação do Liberalismo - CIERL, com escritórios em Genebra, Londres e Nova lorque, além de uma revista, intitulada Cahiers du Libéralisme. Essa organização poderia ser vista como uma primeira tentativa de criar uma "internacional" neoliberal.

A retomada da iniciativa neoliberal no pós-Segunda Guerra se deu com a formação da SMP, em 1947. Essa nova formação beneficiou-se de significativo patrocínio financeiro e institucional de fundações empresariais e bancos privados (PLEWHE, 2009). Crescendo fortemente em capilaridade nos EUA e na Europa, a SMP passou a aglutinar, além de acadêmicos predominantemente da área da economia, atores políticos-chaves, jornalistas, líderes corporativos, think tanks. Segundo Dieter Plewhe (2009, p. 22), "os arquitetos do pensamento coletivo neoliberal conectaram e 
Neoliberalismo e Ciência Política: contribuições teóricas sobre a crise da democracia Juarez Rocha Guimarães • Estevão Cruz

combinaram cuidadosamente as principais esferas e instituições para a disputa da hegemonia - academia, a mídia, a política e os negócios".

Philip Mirowski e Dieter Plewhe (2009) apresentam, além da gênese do neoliberalismo, as origens de algumas tradições nacionais e as estratégias adotadas para aplicar o programa de pesquisa e a plataforma política orientada pela SMP. A partir dessa obra e recorrendo ao esquema analítico de Stephanie Lee Mudge (2008), que observa os desenvolvimentos históricos do neoliberalismo como uma colaboração entre os campos intelectual, político e burocrático, reproduzimos a tabela que resume o período de ascensão do neoliberalismo em quatro países-chaves: França, Inglaterra, Alemanha e Estados Unidos (CRUZ, 2019, p. 88)5:

Tabela 1: Síntese do desenvolvimento histórico do neoliberalismo nos primeiros anos do pós-II Guerra

\begin{tabular}{|c|c|c|c|}
\hline & Campo Intelectual & Campo Político & $\begin{array}{c}\text { Campo } \\
\text { Burocrático }\end{array}$ \\
\hline $\begin{array}{l}\text { PAÍSES } \\
\text { Problemática } \\
\text { central }\end{array}$ & $\begin{array}{c}\text { Expressão do } \\
\text { desenvolvimento } \\
\text { dos temas teóricos } \\
\text { relacionados ao } \\
\text { programa de } \\
\text { pesquisa do CWL e } \\
\text { da SMP }\end{array}$ & $\begin{array}{c}\text { Expressão } \\
\text { das posições } \\
\text { políticas (think } \\
\text { tanks, grupos } \\
\text { empresariais, } \\
\text { partidos) sobre } \\
\text { as questões } \\
\text { relacionadas ao } \\
\text { mercado e ao } \\
\text { Estado }\end{array}$ & $\begin{array}{c}\text { Implementação de } \\
\text { políticas e esforços } \\
\text { para realização } \\
\text { do programa } \\
\text { neoliberal }\end{array}$ \\
\hline \multicolumn{4}{|c|}{ FRANÇA (DENORD, 2009) } \\
\hline $\begin{array}{c}\text { Questão } \\
\text { intervencionista: } \\
\text { tensão entre os } \\
\text { campos intelectual } \\
\text { e político }\end{array}$ & $\begin{array}{l}\text { A partir do CWL, } \\
\text { criação do CIERL; } \\
\text { Louis Rugier, } \\
\text { Jacques Rueff e } \\
\text { Maurice Allais } \\
\text { com posições anti- } \\
\text { laissezfairianas e } \\
\text { anti-coletivistas }\end{array}$ & $\begin{array}{c}\text { Association de la } \\
\text { Libre Entreprise } \\
\text { e radicalização } \\
\text { da agenda pró- } \\
\text { mercado livre }\end{array}$ & $\begin{array}{l}\text { Participação de } \\
\text { Rueff na política } \\
\text { governamental, } \\
\text { assessorando } \\
\text { os planos } \\
\text { econômicos } \\
\text { Pinay-Rueff (1958) } \\
\text { e depois com o } \\
\text { plano Armand- } \\
\text { Rueff (1959-1962) }\end{array}$ \\
\hline
\end{tabular}

5 Como afirmamos antes (CRUZ, 2019, p. 75), a escolha desses países justifica-se por duas razões: primeiro, foram os países centrais do capitalismo do pós-Segunda Guerra; segundo, a esmagadora maioria dos membros da SMP era vinculada a esses países, inseridos, sobretudo, nas instituições acadêmicas e no mundo dos negócios. 


\begin{tabular}{|c|c|c|c|}
\hline \multicolumn{4}{|c|}{ INGLATERRA (TRIBE, 2009) } \\
\hline $\begin{array}{c}\text { Envolvimento } \\
\text { com a política } \\
\text { governamental } \\
\text { e força do } \\
\text { keynesianismo } \\
\text { no campo } \\
\text { intelectual desloca } \\
\text { o neoliberalismo } \\
\text { inglês para o } \\
\text { campo político }\end{array}$ & $\begin{array}{c}\text { Influência de Hayek, } \\
\text { Lionel Robbins, } \\
\text { Arnold Plant e John } \\
\text { Jewkes, membros } \\
\text { da London School of } \\
\text { Economics, contra o } \\
\text { liberalismo social e } \\
\text { o keynesianismo de } \\
\text { Cambridge }\end{array}$ & $\begin{array}{l}\text { A partir dos anos } \\
1950 \text { a maioria } \\
\text { dos participantes } \\
\text { foram figuras } \\
\text { ligadas a grupos } \\
\text { de pressão e } \\
\text { think tanks, como } \\
\text { o Institute of } \\
\text { Economic Affairs, } \\
\text { criado em } 1955\end{array}$ & $\begin{array}{l}\text { Coordenação } \\
\text { da economia } \\
\text { de guerra por } \\
\text { Robbins e } \\
\text { montagem do } \\
\text { quadro político } \\
\text { que influencia } \\
\text { os primeiros } \\
\text { governos do pós- } \\
\text { Segunda Guerra }\end{array}$ \\
\hline \multicolumn{4}{|c|}{ ALEMANHA OCIDENTAL (DARDOT; LAVAL, 2017; PTAK, 2009; FOUCAULT, 2008) } \\
\hline $\begin{array}{l}\text { Permanência da } \\
\text { Escola de Freiburg } \\
\text { durante regime } \\
\text { Nazi, reflexão } \\
\text { dos intelectuais } \\
\text { exilados e } \\
\text { contexto pós- } \\
\text { Segunda Guerra } \\
\text { favorecem } \\
\text { integração dos } \\
\text { campos intelectual } \\
\text { e burocrático }\end{array}$ & $\begin{array}{l}\text { Preocupação com } \\
\text { o quadro político- } \\
\text { jurídico (Escola de } \\
\text { Freiburg: Walter } \\
\text { Eucken e Franz } \\
\text { Böhn) e com o } \\
\text { quadro social e } \\
\text { moral/Vitalpolitik } \\
\text { (Röpke, Rüstow } \\
\text { e Alfred Müller- } \\
\text { Armack) da ordem } \\
\text { de mercado }\end{array}$ & $\begin{array}{l}\text { Não há uma } \\
\text { referência } \\
\text { relevante de } \\
\text { ação diretamente } \\
\text { nesse campo }\end{array}$ & $\begin{array}{l}\text { Papel central de } \\
\text { Ludwig Erhard na } \\
\text { implantação da } \\
\text { “Economia Social } \\
\text { de Mercado" na } \\
\text { reconstrução na } \\
\text { Bizona - área de } \\
\text { influência dos EUA } \\
\text { e Inglaterra - no } \\
\text { pós- II Guerra. }\end{array}$ \\
\hline \multicolumn{4}{|c|}{ ESTADOS UNIDOS (HORN; MIROWSKI, 2009) } \\
\hline $\begin{array}{l}\text { Desenvolvimento } \\
\text { marcado pela } \\
\text { articulação } \\
\text { entre grupos } \\
\text { empresariais e } \\
\text { Universidade de } \\
\text { Chicago - "Projeto } \\
\text { Hayek" e "Projeto } \\
\text { Livre Mercado" }\end{array}$ & $\begin{array}{l}\text { Criação da Escola } \\
\text { de Chicago, com } \\
\text { envolvimento } \\
\text { central de Hayek, } \\
\text { Henry Simons, } \\
\text { Aaron Director e } \\
\text { Friedman }\end{array}$ & $\begin{array}{c}\text { Envolvimento } \\
\text { determinante } \\
\text { dos grupos } \\
\text { empresariais, } \\
\text { especialmente } \\
\text { o Volker Fund, e } \\
\text { think tanks como } \\
\text { a Foundation } \\
\text { for Economic } \\
\text { Education }\end{array}$ & $\begin{array}{c}\text { Os neoliberais } \\
\text { estadunidenses } \\
\text { não tiveram papel } \\
\text { fundamental } \\
\text { na implantação } \\
\text { das políticas } \\
\text { governamentais } \\
\text { antes do governo } \\
\text { Reagan }\end{array}$ \\
\hline
\end{tabular}

Ao longo da década de 1970 confluem diversas crises que marcam um novo período de formação da agenda neoliberal, que predominaria nas décadas seguintes. A crise da economia internacional dos anos 1970, interrompendo o crescimento continuado das três décadas anteriores, o aumento das pressões por novos direitos redistributivos e de reconhecimento, as guerras de independência e descolonização, a queda de regimes fascistas remanescentes na Europa e a emergência de ditaduras militares na 
Neoliberalismo e Ciência Política: contribuições teóricas sobre a crise da democracia Juarez Rocha Guimarães • Estevão Cruz

América do Sul, tudo isso configurou uma crise do compromisso e desconstrução do homo politicus marshallianus (ABREU, 2008, p. 301). A resposta programática neoliberal veio com a ascensão de Ronald Reagan e Margareth Thatcher aos governos dos EUA e da Inglaterra, inaugurando um novo período militante (DARDOT; LAVAL, 2016, p. 242) ou combativo (DAVIES, 2016) de afirmação do neoliberalismo.

Registrou-se acima o modo como, nas décadas anteriores, os atores neoliberais organizaram-se para a construção de nova hegemonia, posicionando-se em esferas e instituições chaves e promovendo articulações entre o campo intelectual, político e burocrático, criando condições para apresentar o que Hayek (1985, p. XLI) chamou de um "equipamento intelectual de emergência" para o momento de crise. Esse senso estratégico e de oportunidade dos neoliberais comparece na própria compreensão de Friedman (2002, p. XIV) de que

somente uma crise - real ou percebida - produz uma mudança verdadeira. Quando essa crise ocorre, as ações que são tomadas dependem das ideias que estão por aí. Essa, acredito, é nossa função básica: desenvolver alternativas para as políticas existentes, mantê-las vivas e disponíveis até que o politicamente impossível se torne politicamente inevitável.

Nesse momento, a "Comissão Trilateral" surgia como centro de articulação das elites políticas e econômicas dos EUA, Europa Ocidental e Japão, voltado para a elaboração de políticas que promovessem seus interesses ${ }^{6}$. Segundo Dardot e Laval (2016, p. 72), a Comissão Trilateral poderia ser considerada como parte do esforço de construção da hegemonia neoliberal. Partiu dela a formulação de uma resposta paradigmática à crise do liberalismo democrático marshalliano, o documento The Crisis of Democracy: report on the governability of democracies to the trilateral comission,

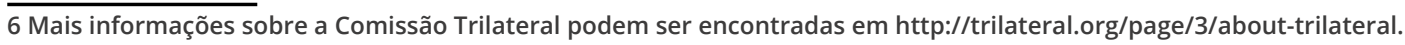


Neoliberalismo e Ciência Política: contribuições teóricas sobre a crise da democracia Juarez Rocha Guimarães • Estevão Cruz

assinado por Michel Crozier, Samuel Huntington e Joji Watanuki $(1975)^{7}$.

No documento, os autores faziam previsões pessimistas acerca do futuro da democracia e também da economia. Um dos seus principais argumentos guardava inequívoca aproximação com o pensamento político neoliberal sobre a democracia, ou seja, o de que o desafio mais sério enfrentado pelos governos democráticos dizia respeito à não limitação da vontade popular que acarreta, consequentemente, aumento de participação e de demandas redistributivas. Jacques Rancière (2014, p. 16) foi sintético ao comentar a conclusão do documento: “o que provoca a crise do governo democrático nada mais é do que a intensidade da vida democrática".

Thatcher e Reagan, em diálogo com esse documento, apresentavam seu programa político como, antes de tudo, um conjunto de respostas para a crise de ingovernabilidade da democracia. Segundo Dardot e Laval (2016, p. 194), esse diagnóstico apareceria, ainda, no programa político de diversos outros governos e seria assumido pelos organismos internacionais como FMI e Banco Mundial. A defesa de certo entendimento da liberdade vinculada ao ethos mercantil contra o Estado do Bem-Estar Social centralizaria uma nova agenda que combinava privatização, desregulamentação, políticas de austeridade e dimensões autoritárias e conservadoras no plano da autoridade. Começava a se fechar o horizonte de uma progressiva extensão e universalização dos direitos de cidadania, dando lugar a desempregos estruturais, crescimento das desigualdades sociais, regressão de direitos feministas, em um quadro de crescente mal-estar democrático.

A década de 1990 deveria ser compreendida como o início da hegemonia neoliberal, com as derrotas dos paradigmas do chamado liberalismo social ou igualitário, com a formação do New Labour na Inglaterra, a derrota do keynesianismo no Partido Democrático

\footnotetext{
7 A "virada neoliberal" não pode ser resumida a uma disputa discursiva em torno da questão democrática, mas é nela que centralizamos a atenção, tendo em vista o objetivo do artigo. Para uma leitura sobre a formação de uma nova "classe capitalista transnacional", que coordena uma mudança subjetiva e objetiva na disposição em relação ao compromisso marshalliano e ao financiamento do Estado, indicamos: CAROLL; SAPINSKI (2009), STREECK (2013), DUMÉNIL; LÉVY (2004).
} 
Neoliberalismo e Ciência Política: contribuições teóricas sobre a crise da democracia Juarez Rocha Guimarães • Estevão Cruz

dos EUA e o Tratado de Maastricht, em 1992, que consagrava uma linha claramente neoliberal como referência para o processo de unificação da Europa. De forma crescente, nos anos seguintes, as disputas e divisões políticas nas democracias liberais ocidentais passaram a ocupar um campo estreitado pelas políticas neoliberais - resumido na insígnia thatcherista There Is No Alternative --, gerando fortes crises de identidade em partidos socialdemocratas, eurocomunistas e trabalhistas e, também, nos chamados novos movimentos sociais.

Nesse sentido, vale destacar um trecho do manifesto "A terceira via e o novo centro", assinado por Tony Blair (Partido Trabalhista) e Gerhard Schröder (Partido Social-Democrata Alemão), relembrado por Dardot e Laval (2016, p. 234), que declara ser o objetivo da esquerda moderna oferecer "um quadro sólido para uma economia de mercado competitiva [...] um quadro que permita às forças de mercado funcionar convenientemente". O trecho indica a indisfarçável assimilação da linguagem política e do programa neoliberal. Destaca-se também o que Nancy Fraser (2017) identificou como "neoliberalismo progressista", ou seja, a "aliança entre, de um lado, correntes majoritárias dos novos movimentos sociais (feminismo, antirracismo, multiculturalismo e direitos LGBT) e, de outro lado, um setor de negócios baseado em serviços com alto poder 'simbólico' (Wall Street, o Vale do Silício e Hollywood)".

Enfim, seria preciso anotar o recrudescimento do neoliberalismo em um sentido autoritário após a grande crise internacional de 2008 (BRUFF, 2016; 2014). Para o cientista político Wolfgang Streeck (2013), o período aberto com essa crise marca o ponto alto da longa transformação neoliberal do capitalismo democrático do pós-Segunda Guerra, em que a tensão entre os princípios da "justiça social" e da "justiça de mercado" se tornou tão aguda que os caminhos do capitalismo e da democracia se separariam. Identificando uma manifesta diferença em relação aos períodos anteriores, William Davies (2016) argumenta que atualmente o neoliberalismo segue dominante, mas não se apoia mais em uma normatividade ou autoridade democrática. Mais recentemente, 
Neoliberalismo e Ciência Política: contribuições teóricas sobre a crise da democracia Juarez Rocha Guimarães • Estevão Cruz

Davies (2018) registra o impulso neoliberal para minar a política democrática em três sentidos: manipulação do sentimento popular com mobilização de uma moralidade conservadora, reforço da tecnocracia e de práticas e linguagens da governança empresarial e aumento do poder discricionário do Executivo. Nesse mesmo sentido, lan Bruff $(2016$, p. 107) destaca que "uma coerção dirigida pelo Estado, insulada das pressões democráticas, é central para a criação e manutenção desta ordem político-econômica, defendendo-a contra pressões em favor de maior igualdade e democratização". O argumento do autor é que essas dimensões autoritárias seriam a expressão de uma forte crise de legitimidade dos Estados guiados por dinâmicas neoliberais.

O horizonte do homo politicus marshallianus, que apostava no progressivismo intrínseco à dinâmica da democracia liberal, ver-se-ia assim triplamente fechado: pelas dinâmicas econômicas que levam ao desemprego estrutural e às crises fiscais permanentes do Estado, pelas dinâmicas políticas que corroem os espaços de criação e efetivação dos direitos de cidadania e por uma nova cultura neoliberal que mina os pressupostos da solidariedade e do igualitarismo como valores estruturantes da sociabilidade.

\section{Um novo princípio de legitimação do Estado}

Após identificar a singularidade e o pluralismo da tradição neoliberal e estruturar uma narrativa histórica das suas formação e expansão política, é necessário definir o neoliberalismo como um novo princípio de legitimação do Estado, antagonista e alternativo àquele liberal social ou igualitário dominante nas décadas do pós-Segunda Guerra.

Este trabalho é afim aos esforços do chamado institucionalismo discursivo que, segundo Daniel Béland e Robert Henry Cox (2011), destacam a relevância das ideias, valores e crenças políticas para fundamentar a ação dos agentes políticos em relação, 
Neoliberalismo e Ciência Política: contribuições teóricas sobre a crise da democracia Juarez Rocha Guimarães • Estevão Cruz

sobretudo, aos processos de institucionalização e desinstitucionalização. Como afirma Adolfo Garcé (2015, p. 200), essa abordagem não deveria surpreender a Ciência Política, uma vez que autores "clássicos" como Robert Dahl, Giovanni Sartori e Philippe Schmitter tinham clareza do papel das "crenças dos ativistas", da "ideologia" e da "informação especializada" para os processos políticos.

Garcé (ibidem, p. 208) sustenta que as instituições podem ser entendidas como o resultado de "correlações de forças entre atores" que "levam a marca das crenças e valores de seus fundadores". Nesse sentido, converge com as hipóteses de relações causais entre ideias, interesses e instituições elencadas por Mark Blyth (2002, p. 33-44 apud GARCÉ, p. 209), segundo as quais:

a) em tempos de crise, são as ideias e não as instituições que reduzem a incerteza; $b$ ) as ideias são recursos para a ação coletiva e para a construção de coalizões; c) os atores usam as ideias nas lutas para erodir a legitimidade das instituições existentes; d) as ideias são guias nos quais os atores se apoiam para construir novas instituições; e) as ideias, uma vez incorporadas nas instituições, tornam possível a estabilidade institucional.

É interessante notar que a percepção sobre a importância da relação entre as ideias e a mudança institucional, formando um novo princípio de legitimação do Estado, é compartilhada de forma cristalina por Hayek em diversos momentos. Para ele, "um dos pontos fundamentais da doutrina liberal é a convicção de que, em última análise, o rumo do progresso é determinado pelas ideias e, portanto, pelos homens que divulgam novas ideias" (HAYEK, 1983, p. 129). Por isso, desde The Road to Serfdom, Hayek (2010 [1944], p. 221) considerou que a crítica das ideias dominantes seria o ponto de partida para um "novo, longo e árduo processo pelo qual todos nós esperamos criar pouco a pouco um mundo muito diferente daquele que conhecemos nos últimos vinte e cinco anos". Além disso, seria necessário elaborar sistematicamente uma filosofia da liberdade, pois "se quisermos vencer a grande luta que se está travando no campo das ideias, devemos, antes de mais nada, saber 
Neoliberalismo e Ciência Política: contribuições teóricas sobre a crise da democracia Juarez Rocha Guimarães • Estevão Cruz

em que acreditamos. Devemos também ter ideia clara daquilo que desejamos preservar" (HAYEK, 1983, p. 20). Mas essa não seria uma batalha abstrata, encerrada no campo etéreo das ideias, e deveria dirigir-se a uma nova formulação institucional com a proposição de um "equipamento intelectual de emergência para o momento - talvez não muito distante - em que o colapso das instituições existentes se torna inequívoco" (1985, p. XLI). Em síntese, para Hayek (1983, p. 132) "se a política é a arte do possível, a filosofia política é a arte de tornar politicamente possível o aparentemente impossível".

Não se trata de conceber uma análise idealista da política. O propósito aqui é, ao contrário, evidenciar como a práxis de construção de um novo princípio de legitimação do Estado estrutura visões de mundo, valores e crenças em uma linguagem política orgânica a interesses e projetos políticos em conflito. A questão é a de compreendermos como um novo princípio de legitimação neoliberal do Estado pôde se instaurar profundamente e desorganizar o consenso marshalliano do pós-Segunda Guerra.

Nesse sentido, a experiência do governo Thatcher é bastante significativa. Convém lembrar, como fazem Damien Cahill e Martijn Konigs (2017), que Margareth Thatcher manifestava publicamente sua admiração por Hayek e nutria a expectativa de que seu governo tivesse sucesso em implementar algumas ideias do pensador neoliberal. Em diversos artigos pioneiros publicados nos anos 1970 e 1980, compilados em The Hard Road to Renewal: Thatcherism and the Crisis of the Left, Stuart Hall (1990, p. 2) observou que a ascensão de Thatcher não era uma mudança de governo rotineira, mas "a quebra decisiva com o consenso do pós-guerra, a profunda reconfiguração da vida social que colocou em marcha".

Nesses trabalhos, Hall não se contenta com uma explicação de que a eleição de Thatcher e a consolidação do seu poder se deveram simplesmente a uma reação classista das elites econômicas aos governos trabalhistas que predominaram no período anterior. Se essa reação era incontestável, materializada numa política agressiva de confronto com os sindicatos, de aumento do 
Neoliberalismo e Ciência Política: contribuições teóricas sobre a crise da democracia Juarez Rocha Guimarães • Estevão Cruz

desemprego, de desestruturação do Welfare State, ela não explicava em si mesma o forte apoio popular e eleitoral que Thatcher conquistou nas classes trabalhadoras.

Para Hall (1990, p. 2), a grande novidade do "Thatcherismo" seria a implementação de um projeto político-cultural de "modernização regressiva", reiterando e ressignificando valores políticos tradicionais enraizados no senso comum inglês - "uma forma de pensamento cotidiano que nos oferece um enquadramento de significados que confere sentido ao mundo" (HALL; O'SHEA, 2013, p. 8). Isto é, o Thatcherismo forjaria "uma nova articulação discursiva entre os discursos liberais do livre mercado e do homem econômico e os temas conservadores orgânicos da tradição, família e nação, respeitabilidade, patriarcado e ordem" (HALL, 1990, p. 2). O Thatcherismo expressaria, assim, a formação de um novo projeto hegemônico que, como ele depois expressou (HALL, 2011), se referiria mesmo a uma "revolução neoliberal".

Hall $(1990$, p. 7) retoma a noção gramsciana de hegemonia no sentido de afastar as "noções mecanicistas de que o Thatcherismo seria apenas outro nome para o exercício da mesma, antiga, familiar e classista dominação pelas mesmas, antigas, familiares e classes dirigentes". Segundo o autor (ibidem, p. 3), ao contrário da perspectiva corporativista e eleitoralista típica da visão social-democrata do Labour Party, o Thatcherismo se destacou por possuir uma "concepção expandida, multifacetada e hegemônica da política como 'guerra de posição'". Isso significou (ibidem, p. 7)

a luta para contestar e desorganizar uma formação política existente; a tomada de "liderança" [...] sobre várias esferas diferentes da sociedade de uma só vez - economia, sociedade civil, na vida intelectual e moral, cultura; a condução de tipos amplos e diferenciados de lutas; a conquista de um patamar estratégico de consentimento popular; e, então, a garantia de uma autoridade social suficientemente profunda para conformar a sociedade em um novo projeto histórico. 
Neoliberalismo e Ciência Política: contribuições teóricas sobre a crise da democracia Juarez Rocha Guimarães • Estevão Cruz

No longo prazo, a consolidação de um projeto hegemônico transforma o senso comum, legitimando as mudanças políticas. Assim, Hall e Alan O'Shea (2013, p. 11) identificam que "após quatro décadas de uma concertada investida ideológica neoliberal, esta nova versão do senso comum está rapidamente se tornando dominante". Esse novo senso comum neoliberal significa que "as atitudes amplamente igualitárias e coletivistas que sustentaram a era do Estado do Bem-Estar Social estão dando lugar a uma perspectiva mais competitiva, individualista mercantil, empreendedora e orientada para o lucro" (HALL; O'SHEA, 2013, p. 11).

A interpretação de Hall sobre o Thatcherismo está centrada no contexto político da Inglaterra, mas poderia ter a sua validade mais generalizável se tomamos a posição de Dardot e Laval (2016) de que o neoliberalismo deve ser entendido como uma nova razão de mundo que promove, globalmente e atravessando todas as experiências de vida, o princípio do capitalismo contemporâneo. $O$ neoliberalismo procura fazer da concorrência a norma de conduta e da empresa o modelo de subjetivação, produz certos tipos de relações sociais, certas maneiras de viver, e afeta a forma da nossa existência (DARDOT; LAVAL, 2016, p. 16-17).

Como o neoliberalismo se incorpora nas organizações e imaginações sociais como uma visão de mundo baseada na racionalidade econômica mercantil? São vários os caminhos para uma resposta, mas Nick Couldry (2010) oferece uma importante indicação ao ligar a formação desse novo senso comum neoliberal aos processos de mudança nos meios de comunicação, que teriam promovido um inusitado processo de erosão do direito público à voz dos cidadãos, de falar e ser ouvido e ouvida nas democracias. Isto é, um dos modos de normalização do neoliberalismo se dá pela interdição dos processos democráticos de formação do próprio povo e da vontade popular, que ocorrem pela democratização do direito à voz, ou seja, pela universalização das capacidades dos indivíduos para criar e expressar uma narrativa de si mesmos e do mundo (COULDRY, 2010). 
Neoliberalismo e Ciência Política: contribuições teóricas sobre a crise da democracia Juarez Rocha Guimarães • Estevão Cruz

No lugar da universalização do direito público à voz dos cidadãos, identifica-se um fenômeno massivo de concentração de poder e capital na indústria de mídia. Essa concentração opera uma das facetas da convergência midiática, que implicaria o controle de diferentes tecnologias por um grupo restrito de grandes conglomerados empresariais, que, por sua vez, articulam a ampliação do seu alcance midiático à formação de um novo senso comum, criando novos significados mercantis para a vida social (CUPPLES; GLYNN, 2016). Jason Hickel (2016, p. 145) exemplifica esse processo apontando que "no início dos anos 1980, 50 empresas controlavam 90\% de toda a mídia americana; até 2011, essa mesma parcela de 90\% passou a ser controlada por apenas seis empresas".

\section{A formação de um Estado Neoliberal}

A consolidação do neoliberalismo como um novo princípio de legitimação do Estado relaciona-se com a determinação de criar uma nova estrutura social e uma nova institucionalidade estatal. Assim, o neoliberalismo tem sustentado de modo diferenciado nas democracias liberais, na dependência das heranças institucionais e das resistências, um amplo movimento de mudança legal e constitucional das regras, instituições e procedimentos, que formam um novo modo de vida e se institucionalizam em uma nova forma de regulação dos conflitos políticos na sociedade e no mercado8 ${ }^{8}$.

Gerardo Pisarello (2014) define esse movimento de mudanças provocadas pelo neoliberalismo como um processo de ruptura desconstituinte desdemocratizadora. Esses processos seriam “uma série de dinâmicas de mudanças, jurídicas e não jurídicas, implantadas entre a crise dos regimes que são questionados até a sedimentação de novas ordens político-constitucionais" (PISARELLO, 2014, p. 12). O caráter desconstituinte do neoliberalismo deve-se ao sentido de regressão em relação ao paradigma constitucional vigente no

8 Os estudos de Antonio Gramsci sobre o "Americanismo e Fordismo" servem como uma referência analítica. Escreve Gramsci (2007, p. 258-9): "A americanização exige um determinado ambiente, uma determinada estrutura social (ou a decidida vontade de criá-la) e um determinado tipo de Estado". 
Neoliberalismo e Ciência Política: contribuições teóricas sobre a crise da democracia Juarez Rocha Guimarães • Estevão Cruz

pós-Segunda Guerra. Essa ruptura desconstituinte seria também desdemocratizadora, pois impulsionaria dinâmicas de esvaziamento do conteúdo democrático e das garantias das constituições vigentes (ibidem, p. 15). Essas mudanças abarcariam, pelo menos, cinco áreas de forma interdependente.

Na regulação da economia, em que talvez tenham sido mais estudadas e empiricamente documentadas ${ }^{9}$, vão das leis de regulação dos fluxos financeiros e da autarquização dos bancos centrais em relação aos controles democráticos aos regimes de tributação e incentivos fiscais, aos processos orçamentários e de controle fiscal, aos regimes de propriedade de empresas e bens públicos, aos modos de regulação urbana e rural, à regulação da exploração das riquezas naturais. Um capítulo decisivo tem sido a mudança do regime de exploração da força de trabalho, sempre no sentido de ir corroendo as bases do direito do trabalho e estabelecendo um novo padrão precarizado de exploração.

Uma segunda área tem sido aquela abarcada pelo nome genérico de políticas do Estado do Bem-Estar Social, relativos à oferta de previdência, saúde, educação, assistência pública e habitação (KERSTENETZKY, 2012). As mudanças nessa área têm sido sempre na direção de novas regras legais, baseadas nos princípios da não universalidade ou focalização, da oferta mercantil e não pública de serviços, da perda de padrões igualitários e interdependentes de serviços. Se não é exato falar em desmonte dos Estados do BemEstar Social, seria possível falar de uma crise da sua legitimidade ou das suas perspectivas históricas de reprodução, conformando um padrão em geral defensivo das políticas sociais nas últimas décadas.

Uma terceira área, como bem anota Loic Wacquant (2012), é o crescimento e a glorificação do braço penal do Estado, que constituem um componente essencial do Leviatã neoliberal. Tratase da superação do chamado Estado do Welfare penal, todo ele construído para uma sociologia da prevenção e para a reinserção

9 Como referência mais atual, indicamos a consulta das seções IV (The State) e V (Social and Economic Restructuring) do livro The Sage Handbook of Neoliberalism, editado por Damien Cahill, Melinda Cooper, Martijn Konigs e David Primrose (Sage Publications, 2018). 
Neoliberalismo e Ciência Política: contribuições teóricas sobre a crise da democracia Juarez Rocha Guimarães • Estevão Cruz

do condenado a um lugar na sociedade como cidadão, para uma escalada punitiva centrada na vigilância das populações marginais, no encarceramento massivo e nas políticas chamadas de "tolerância zero". Cabe destacar a relação direta entre essa mudança e o recrudescimento do regime racial sob o neoliberalismo.

Uma quarta alteração fundamental tem se dado na área da comunicação pública com efeitos extremamente danosos para uma cultura do pluralismo democrático, da tolerância e da formação de esferas públicas dialógicas. Trata-se da erosão dos princípios da oferta e regulação pública da comunicação, desfazendo mesmo a chamada Teoria da Responsabilidade Social da Imprensa, a qual, no âmbito de um sistema liberal, procurava garantir através da regulação anti-truste, do incentivo ao pluralismo social e regional, do direito de resposta e da criminalização dos discursos do ódio, padrões mínimos de pluralismo político nas mídias. Em um ambiente de desregulação democrática, a chegada das novas tecnologias de informação, desconfirmando previsões otimistas originais, tem gerado efeitos massivos de fraude e corrupção da opinião pública.

Por fim, a própria dinâmica da competição partidária eleitoral tem passado por mudanças em seu regime de regulação, no que diz respeito ao financiamento empresarial de campanha e à influência do poder econômico nas dinâmicas eleitorais, em processos de autarquização dos sistemas de representação, envolvidos em dinâmicas corporativas (Cf. MAIR, 2013). Assim, é o próprio cerne do sentido igualitário da universalização do direito de voto e da expressividade dos sistemas de representação que tem sido afetado.

Essas mudanças neoliberais no Estado institucionalizam um deslocamento na correlação de forças extremamente desfavorável às mulheres e às pessoas não-brancas. Como afirma Lisa Adkins (2018), além de ter efeitos desastrosos para a subjetivação das mulheres, a racionalidade neoliberal reorganizaria a ordem de gênero para superar as fronteiras rígidas da divisão sexual do trabalho da época keynesiana e submeter as mulheres aos imperativos do trabalho assalariado, como sujeitos críticos à acumula- 
Neoliberalismo e Ciência Política: contribuições teóricas sobre a crise da democracia Juarez Rocha Guimarães • Estevão Cruz

ção capitalista e à ordem competitiva. Para Wendy Brown (2015), o neoliberalismo também requalifica as tarefas domésticas sob a responsabilidade das mulheres, que passam a ser compreendidas como uma espécie de investimento na formação de capital humano. Michael Omi e Howard Winant (2015, p. 275), por sua vez, destacam que o neoliberalismo tem "como núcleo um projeto racial tanto quanto um projeto de acumulação capitalista" e poderia ser compreendido como racialmente reacionário.

\section{Neoliberalismo e crise das democracias}

Ao longo deste artigo, procurou-se sistematizar, refletir e orientar uma ampla literatura internacional sobre o neoliberalismo com o objetivo de trabalhar o seu conceito político e tornar o seu uso mais rigoroso, delimitado e regulado na Ciência Política. Como formulou Hall (2011), esse é seguramente um trabalho de aproximações sucessivas do conceito, a ser sempre historicizado e pensado empiricamente em suas mediações. Não se trata de pretender retirar o sentido polêmico ou crítico do conceito, mas de torná-lo mais operacional e dialógico, mesmo para aqueles que são contrários ao seu uso.

Na primeira parte, procurou-se dar um tratamento de filosofia política ao conceito de neoliberalismo, inscrevendo-o na tradição histórica do liberalismo, mas mostrando o seu sentido diverso do liberalismo clássico e fortemente crítico ao chamado liberalismo social ou igualitário. O reconhecimento do seu pluralismo de correntes doutrinárias e teóricas fez-se paralelamente à identificação de um núcleo comum de ideias forças.

Na segunda parte, apoiando-se na ampla literatura internacional já formada, foram construídas as linhas gerais de uma grande narrativa histórica da gênese do neoliberalismo do fim dos anos 1930 até os dias de hoje, identificando sua ascensão até a conquista de governos centrais, sua polarização de agenda a partir dos 
Neoliberalismo e Ciência Política: contribuições teóricas sobre a crise da democracia Juarez Rocha Guimarães • Estevão Cruz

anos 1980, sua condição hegemônica em relação ao liberalismo social nos anos 1990 e, enfim, seu curso mais nitidamente antidemocrático nos anos recentes. Em síntese, buscou-se identificar o fechamento de horizontes históricos do que se chamou aqui de homo politicus marshallianus, com novas barreiras histórico-estruturais ao progressivismo liberal.

Na terceira parte, procurou-se evidenciar como o princípio de legitimação das ordens democráticas do liberalismo social ou socialdemocratas do pós-Segunda Guerra foi forte e profundamente alterado com a ascensão do princípio de legitimação neoliberal. Essa mudança na cultura cívica produziu, ao longo de mais de quatro décadas, um novo senso comum que combina um forte ethos mercantil a valores tradicionalistas ou conservadores, formando bases sociais de apoio e eleitorais para um trabalho de mudança das constituições, leis e instituições da democracia liberal.

A quarta parte, enfim, procurou sintetizar essas mudanças globais da institucionalidade do Estado liberal, a ser identificada em cada caso histórico concreto, a partir das diferenciações de herança e de resistência às mudanças. Alcançando as áreas da economia e das políticas sociais, a regulação do trabalho, o regime legal penal, a regulação dos meios de comunicação de massa e o próprio regime de competição eleitoral, essas mudanças teriam institucionalizado uma brutal correlação de forças desfavoráveis às classes trabalhadoras, às mulheres e às pessoas não-brancas.

O artigo propõe que esse conceito político de neoliberalismo, assim trabalhado, pode contribuir para a reflexão sobre a crise das democracias contemporâneas, que tem sido objeto de uma crescente literatura. Essa contribuição poderia se dar em três planos.

O primeiro é o de conformar uma visão histórica mais larga e internacional dessa crise, evitando-se visões impressionistas de curto prazo. Esse conceito político de neoliberalismo permite também realizar estudos comparativos identificando, por exemplo, diferentes graus e modalidades de mudança das regras, instituições e procedimentos do Estado que, apesar de apontarem em 
Neoliberalismo e Ciência Política: contribuições teóricas sobre a crise da democracia Juarez Rocha Guimarães • Estevão Cruz

uma direção semelhante, são sempre singulares. Evitar-se-ia o uso generalizante e impreciso do conceito de neoliberalismo.

O segundo plano é o de fornecer uma visão mais integrativa da crise da democracia, mais afim à sua complexidade. Em geral, modelos explicativos que trabalham com variáveis institucionais, econômicas, sociais e culturais em planos separados, ou estabelecendo correlações causais entre elas, têm dificuldade em construir campos explicativos de um fenômeno que é certamente multideterminado.

O terceiro plano de contribuição do conceito político de neoliberalismo é o de questionar um sentido determinístico das explicações, mostrando como o caminho de ascensão do neoliberalismo foi fruto de uma ação coletiva histórica, de uma vontade política crescentemente formada e empoderada, marcado por várias conjunturas críticas, cuja resolução não estava de antemão garantida. Tudo isso nos ajuda a compreender que o mundo da democracia - sua construção, seus impasses e seus retrocessos - foi desde sempre uma construção política na indeterminação da história.

\section{Referências}

ABREU, Haroldo. Para além dos direitos: cidadania e hegemonia no mundo moderno. Rio de Janeiro: Editora UFRJ, 2008.

ADKINS, Lisa. Neoliberalism's Gender Order. In: CAHILL, Damien et. alli. The SAGE Handbook of Neoliberalism. Londres: SAGE Publications, 2018.

ANDRADE, Daniel P. Neoliberalismo: crise econômica, crise de representatividade democrática e reforço de governamentalidade. Novos Estudos/CEBRAP, v. 38, n.1, p. 109-135, 2019a.

ANDRADE, Daniel P. O que é o neoliberalismo? A renovação do debate nas ciências sociais. Revista Sociedade e Estado, v. 34, n. 1, p. 211-239, 2019b 
Neoliberalismo e Ciência Política: contribuições teóricas sobre a crise da democracia Juarez Rocha Guimarães • Estevão Cruz

AVELINO, Nildo. Foucault e a racionalidade (neo)liberal. Revista Brasileira de Ciência Política (online), n. 21, p. 227-284, 2016. BALL, Terence. Confessions of a conceptual historian. Finnish Yearbook of Political Thought, v. 6, 2002.

BÉLAND, Daniel; COX, Robert Henry (ed.). Ideas and Politics in Social Science Research. New York: Oxford University Press, 2011.

BIEBRICHER, Thomas. The Political Theory of Neoliberalism. Stanford, California: Stanford University Press, 2019.

BIEBRICHER, Thomas. Neoliberalism and Democracy. Constellations, v. 22, n.2, p. 255-266, 2015.

BOAS, Taylor C; GANS-MORSE, Jordan. Neoliberalism: from new liberal philosophy to anti-liberal slogan. Studies in Comparative International Development, v. 44, p. 137-161, 2009.

BROWN, Wendy. Undoing the Demos: neoliberalism stealth's revolution. New York: Zone Book, 2015.

BROWN, Wendy. Nas ruínas do neoliberalismo: a ascensão da política antidemocrática no Ocidente. São Paulo: Editora Filosófica Politeia, 2019.

BRUFF, Ian. Neoliberalism and Authoritarism. In: SPRINGER, Simon et al. (org). The Handbook of Neoliberalism. New York: Routledge, 2016.

BRUFF, lan. The Rise of Authoritarian Neoliberalism. Rethinking Marxism: A Journal of Economics, Culture \& Society, v.26, n.1, p.113-129, 2014.

CAHILL, Damien et al. (eds.). The SAGE Handbook of Neoliberalism. Londres: SAGE Publications, 2018.

CAHILL, Damien; KONIGS, Martijn. Neoliberalism. Cambridge: Polity Press, 2017. 
Neoliberalismo e Ciência Política: contribuições teóricas sobre a crise da democracia Juarez Rocha Guimarães • Estevão Cruz

CAROLL, William K.; SAPINSKI, J.P. Neoliberalism and

Transnational Capitalist Class. In: SPRINGER, Simon et al. (org).

The Handbook of Neoliberalism. New York: Routledge, 2016.

COULDRY, Nick. Why voice matters. London: SAGE Publications Ltd, 2010.

CROUCH, Colin. Copying with Post-Democracy. Fabian

Pamphlets. Londres: Fabian Society, 2001.

CROUCH, Colin. The Strange Non-Death of Neoliberalism.

Cambridge: Polity Press, 2011.

CROZIER, Michel J.; HUNTINGTON, Samuel P.; WATANUKI, Joji. The Crisis of Democracy: report on the governability of democracies to the trilateral comission. Nova York: New York University Press, 1975.

CRUZ, Carlos Estevão Caligiorne. Neoliberalismo e destruição da democracia: uma abordagem marxista na Ciência Política. Belo Horizonte, 2019. 205 f. Dissertação (Mestrado em Ciência Política) - Universidade Federal de Minas Gerais, Belo Horizonte, 2019.

CUPPLES, Julie; GLYNN, Kevin. Neoliberalism, Surveillance and Media Convergence. In: SPRINGER, Simon et al. (eds.). The Handbook of Neoliberalism. New York: Routledge, 2016.

DARDOT, Pierre; LAVAL, Christian. A nova razão do mundo: ensaio sobre a sociedade neoliberal. São Paulo: Boitempo, 2016.

DAVIES, William. The Neoliberal State: Power against 'Politics'. In: CAHILL, Damien et al. (eds.). The SAGE Handbook of Neoliberalism. Londres: SAGE Publications, 2018.

DAVIES, William. The new neoliberalism. New Left Review, vol.101, p. 121-134, 2016.

DENORD, François. French neoliberalism and its divisions. In: MIROWSKI, Philip. PLEWHE, Dieter. The Road from Mont-Pelerin: 
Neoliberalismo e Ciência Política: contribuições teóricas sobre a crise da democracia Juarez Rocha Guimarães • Estevão Cruz

the making of Neoliberal Thought Collective. Cambridge: Harvard University Press, 2009.

DUMÉNIL, Gerard; LÉVY, Dominique. Capital Resurgent: roots of the neoliberal revolution. Cambridge: Harvard University Press, 2004.

DUNN, Bill. Against Neoliberalism as a Concept. Capital\&Class, p. 1-20, 2016.

FOUCAULT, Michel. O Nascimento da Biopolítica. São Paulo: Martins Fontes, 2008.

FRIEDMAN, Milton. Capitalism and Freedom. Chicago e Londres: University of Chicago Press, 40th Anniversary Edition, 2002.

FRASER, Nancy. The end of progressive neoliberalism. Dissent Magazine, 2017. Disponível em: https://www.dissentmagazine. org/online_articles/progressive-neoliberalism-reactionary-populism-nancy-fraser. Acesso em: 26 jan. 2019. (versão traduzida de Henrique Mendes).

GARCÉ, Adolfo. El institucionalismo discursivo como oportunidad: la ciencia politica latino-americana y el estado del arte em la literatura sobre el poder politico de las ideas. Politica y Gobierno, v. XXII, n. 1, p. 199-226, 2015.

GRAMSCl, Antonio. Cadernos do Cárcere: volume 4. Edição e Tradução: Carlos Nelson Coutinho; co-edição: Luiz Sérgio Henriques e Marco Aurélio Nogueira. Rio de Janeiro: Civilização Brasileira, 2007.

HALL, Stuart. The neo-liberal revolution. Cultural Studies, v. 25, n. 6, p. 705-728, 2011.

HALL, Stuart. The Hard Road to Renewal: Thatcherism and the Crisis of the Left. Londres: Verso, 1990.

HALL, Stuart; O'SHEA, Alan. Common-sense neoliberalism. Soundings, n. 55, 2013, pp. 9-25. 
Neoliberalismo e Ciência Política: contribuições teóricas sobre a crise da democracia Juarez Rocha Guimarães • Estevão Cruz

HARVEY, David. O Neoliberalismo: história e implicações. São Paulo: Edições Loyola, 2008.

HAYEK, Friedrich. Direito, Legislação e Liberdade: uma nova formulação dos princípios liberais de justiça e economia política (Volume I Normas e Ordem). São Paulo: Editora Visão, 1985.

HAYEK, Friedrich. O Caminho da Servidão. São Paulo: Instituto Ludwig Von Mises, 2010.

HAYEK, Friedrich. Os Fundamentos da Liberdade. São Paulo: Editora Visão, 1983.

HICKEL, Jason. Neoliberalism and the end of democracy. In: SPRINGER, Simon et al (org). The Handbook of Neoliberalism. New York: Routledge, 2016.

HORN, Rob van; MIROWSKI, Philip. The Rise of the Chicago School of Economics and the Birth of Neoliberalism. In: MIROWSKI, Philip. PLEWHE, Dieter. The Road from Mont-Pelerin: the making of Neoliberal Thought Collective. Cambridge: Harvard University Press, 2009.

KERSTENETZKY, Celia. O Estado de Bem-Estar Social na Era da Razão: a reinvenção do estado social no mundo contemporâneo. Rio de Janeiro: Elsevier Editora, 2012.

LAVAL, Christian. Foucault and Bourdieu: to each his own neoliberalism?. Sociologia e Antropologia, v. 07, n. 1, p. 63-75, 2017. MAIR, Peter. Ruling the void: the hollowing-out of western democracy. Londres, Nova York: Verso, 2013.

MARSHALL, T.H. Cidadania, Classe Social e Status. Rio de Janeiro: Editora Zahar, 1967.

MIROWSKI, Philip, PLEWHE, Dieter. The Road from Mont-Pelerin: the making of Neoliberal Thought Collective. Cambridge: Harvard University Press, 2009.

MUDGE. Stephanie Lee. What is Neo-liberalism?. Socio-Economic Review, n. 6, p. 703-731, 2008. 
Neoliberalismo e Ciência Política: contribuições teóricas sobre a crise da democracia Juarez Rocha Guimarães • Estevão Cruz

OMI, Michel; WINANT, Howard. Racial Formation in the United States. New York: Routledge, 2014.

PECK, Jamie; BRENNER, Neil; THEODORE, Nik. Actually Existing Neoliberalism. In: CAHILL, Damien et al. (eds). The Sage

Handbook of Neoliberalism. Los Angeles: SAGE, 2018.

PISARELLO, Geraldo. Processos Constituyentes: Caminos para la ruptura democrática. Madrid: Editorial Trotta, 2014.

PLEWHE, Dieter. Introduction. In: MIROWSKI, Philip. PLEWHE, Dieter. The Road from Mont-Pelerin: the making of Neoliberal Thought Collective. Cambridge: Harvard University Press, 2009.

PTAK, Ralf. Neoliberalism in Germany: revisiting the Ordoliberal Foundations of the Social Market Economy. In: MIROWSKI, Philip. PLEWHE, Dieter. The Road from Mont-Pelerin: the making of Neoliberal Thought Collective. Cambridge: Harvard University Press, 2009.

RANCIÈRE, Jacques. O ódio à democracia. São Paulo: Boitempo, 35 2014.

\section{REINHOUDT, Jurgen; AUDIER, Serge. The Walter Lippmann}

Colloquium: the birth os neo-liberalism. New York: Springer, 2018.

SILVA, Ricardo. Historicismo e disputas conceituais na Teoria Política. In: SIMPÓSIO NACIONAL DE HISTÓRIA, 2011, São Paulo. ANPUH: XXVI Simpósio Nacional de História. São Paulo: suporte eletrônico, 2011, p. 1-20.

SPRINGER, Simon et al. (eds). The Handbook of Neoliberalism. New York: Routledge, 2016.

STREECK, Wolfgang. As Crises do Capitalismo Democrático. Revista Novos Estudos/CEBRAP, n. 92. p. 35-56, 2012.

STREECK, Wolfgang. Tempo comprado: a crise adiada do capitalismo democrático. Coimbra: Conjuntura Actual Editora (edição Kindle, Almedina), 2013. 
Neoliberalismo e Ciência Política: contribuições teóricas sobre a crise da democracia Juarez Rocha Guimarães • Estevão Cruz

TRIBE, Keith. Liberalism and Neoliberalism in Britain, 1930-1980. In: MIROWSKI, Philip. PLEWHE, Dieter. The Road from MontPelerin: the making of Neoliberal Thought Collective. Cambridge: Harvard University Press, 2009.

TURNER, Rachel S. The 'rebirth of liberalism': the origins of neo-liberal ideology. Jornal of Political Ideologies, v.12, n.1, p. 67-83, 2007.

WACQUANT, Löic, Três etapas para uma antropologia histórica do neoliberalismo realmente existente. Caderno CRH, v. 25, n. 66, 2012, pp. 505-518.

\section{6}

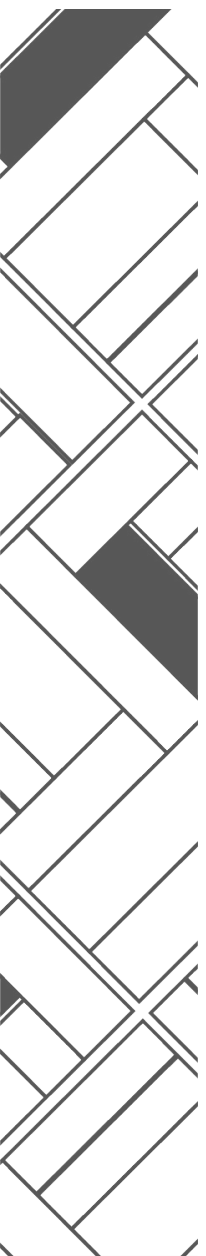

